Reprod. Nutr. Dévelop., 1987, 27 (4), 769-779.

\title{
Valorization of rapeseed meal. 4. Effects of iodine, copper and ferrous salt supplementation in growing rats
}

\author{
M. VERMOREL, J. EVRARD $\left({ }^{*}\right)$
}

with the technical assistance of Y. ANGLARET, Françoise DUBOISSET, Simone GASNET, C. LETOY and R. SOUCHET

I.N.R.A., Laboratoire d'Etude du Métabolisme Energétique, Theix, 63122 Ceyrat, France.

(*) CETIOM, Centre Technique Interprofessionnel des Oléagineux Métropolitains, rue Monge, 33600 Pessac.

Summary. Ten groups of 10 growing male rats $(65 \mathrm{~g})$ were fed ad libitum either a control diet or rapeseed diets $\left(15 \mathrm{mM}\right.$ glucosinolates $/ \mathrm{kg} \mathrm{DM}$ ) supplemented either with $\mathrm{I}^{-}$alone, $\mathrm{1}^{-}$ and $\mathrm{Cu}^{++}\left(2\right.$ levels), $\mathrm{I}^{-}+\mathrm{Cu}^{++}$and methionine or $\mathrm{I}^{-}$and $\mathrm{Fe}^{++}(2$ levels) (table 1$)$ for 35 days. When the rapeseed diets were given as powder or as mash, food intake decreased 24 and $32 \%$, respectively ; live weight gain was reduced by 36 and $46 \%$, liver weight increased 20 and $33 \%$, thyroïd gland was 3 and 4 times as big, and a 30 and $50 \%$ decrease in the T4 plasma level was noted (table 2).

$\mathrm{I}^{-}$supplementation did not prevent the deleterious effects of rapeseed meal feeding. $\mathrm{I}^{-}$and $\mathrm{Fe}^{++}$supplementation had detrimental effects on food intake, live weight gain and kidney weight, but beneficial effects on liver and thyroïd weights and on plasma thyroïd hormone levels.

The low level of $\mathrm{I}^{-}$and $\mathrm{Cu}^{++}$supplementation suppressed the depressive effects of rapeseed meal on food intake and live weight gain and reduced the deleterious effects on kidney, liver and thyroïd weights and on plasma thyroïd hormone levels, whereas the higher level almost suppressed them. The results are discussed considering the likelihood of a bivalent cation effect on glucosinolates.

\section{Introduction.}

Glucosinolates are the most toxic compounds in rapeseed meal and limit its use as animal feed (Bell, 1984). In France, breeding has reduced by 3 to 5 times the glucosinolate content of rapeseed, without reducing productivity, but the content in new varieties such as Tandem and Darmor is still quite high, between 30 and $60 \mathrm{mM} / \mathrm{kg}$ dry matter (DM) of meal (Morice, 1983). The depressive effect of rapeseed on food consumption and growth rate of rats is directly related to the glucosinolate content of the diet (Vermorel, Davicco and Evrard, 1987). In addition, rapeseed cultivars with very low glucosinate contents (Line, Erglu, 
Tower) still have a goitrogenic effect which reduces long-term pig and poultry performance (Just, Hansen and Jensen, 1982 ; Thomke et al., 1983).

Hydrolysis of glucosinolates by the myrosinase contained in the seed or by microorganisms in the animal's gut gives rise to several toxic compounds (Fenwick and Heaney, 1983), in particular isothiocyanates (ITC) and thiocyanate ions which compete with iodine for thyroidal transport and thus decrease iodide uptake (Fenwick and Heaney, 1983), and oxazolidine-2-thione (VTO), which, like goitrin, inhibit iodine oxidation, a key stage in thyroid hormone synthesis (Bergner and Schmidt, 1972). These hormones are essential for tissue growth, especially for protein synthesis. Therefore, this goitrogenic activity of ITC and VTO and the formation of other toxic compounds, such as nitriles, have to be inhibited.

Work by Anke et al. (1980), Kracht, Matzke and Ohle (1983) and Ludke, Schone and Hennig (1985) on growing pigs showed that iodine supplementation of rapeseed-based diets reduced the unfavorable effects of ITC and improved pig performance. In addition, some bivalent cations (zinc, manganese and more especially copper) have an antigoitrogenic effect and favorable action on pig growth. In poultry, ferrous sulphate reduced the goitrogenic effects of glucosinolates from rapeseed meal 30 to $70 \%$, but did not improve animal performance (Menzel, 1983).

The objectives of the present study were to determine : 11 the effects of supplementation with iodine alone, iodine + copper and iodine + iron, on performance, organ weight and thyroid activity of growing rats receiving a glucosinolates-rich diet, 2) the effects of copper and iron supplementation level, 3 ) the influence of dietary preparation (powder or mash), since the performance of pigs receiving rapeseed based diets is better with pelleted than with mash diets (Bourdon, Quere and Baudet, 1982 ; Rundgren, 1983).

Materials and methods.

Feeds and diets. - For this study, a rapeseed meal from the variety Tandem ( $64 \mathrm{mM}$ total glucosinolates, $2.06 \mathrm{~g}$ ITC and $4.88 \mathrm{~g}$ VTO per $\mathrm{kg} \mathrm{DM})$ was selected. The seed was dehulled and treated by both pressure and heating $\left(90^{\circ} \mathrm{C}\right)$, followed by hexane extraction and desolventisation without vapour injection initially at $70^{\circ} \mathrm{C}$ for $40 \mathrm{~min}$., thereafter at $90^{\circ} \mathrm{C}$ for $5 \mathrm{~min}$.

Ten diets containing wheat starch supplemented with minerals, vitamins and lysine or methionine (Vermorel, Davicco and Evrard, 1987) were studied simultaneously. The sole source of protein in the control diet $(122 \mathrm{~g} / \mathrm{kg} \mathrm{DM})$ was herring meal supplemented with methionine. The nine experimental diets contained $235 \mathrm{~g}$ DM rapeseed meal and $15 \mathrm{mM}$ glucosinolates $/ \mathrm{kg} \mathrm{DM}$ to obtain a $50 \%$ reduction in the growth rate of rats according to earlier results (Vermorel, Davicco and Evrard, 1987). The rapeseed meal provided $80 \%$ of protein and herring meal $20 \%$. Protein content was $135 \mathrm{~g} / \mathrm{kg} \mathrm{DM}$, to maintain the same digestible protein/ digestible energy ratio as in the control diet and to meet the amino acid require- 
ments of growing rats. The lysine supply was increased by $1 \mathrm{~g} / \mathrm{kg}$ DM for the rapeseed diets, in case processing the dehulled seed had an effect on lysine availability (Bourdon, Perez and Baudet, 1984). The diets were fed in powder form, similar to pig feed, but two rapeseed diets were given as mash to determine the toxicity of rapeseed meal fed in wet form.

All the rapeseed diets were supplemented with iodine $(1 \mathrm{mg} / \mathrm{kg}$ DM) in the form of potassium iodide, at a level 6 times higher than normal. This high level had given positive results with growing pigs and with poultry (Ludke, Schöne and Henning, 1985 ; Menzel, 1983).

Three rapeseed diets were also supplemented with copper, in the form of copper sulphate, at 315 or $630 \mathrm{mg} \mathrm{Cu}{ }^{++} / \mathrm{kg} \mathrm{DM}$, equivalent to complexing half or all VTO, respectively (table 1). However, the greater supply of copper may lead to the formation of stable cysteine-Cu complexes which would reduce rat performance (Robbins and Baker, 1980). The influence of methionine supplementation $(1.5 \mathrm{~g} / \mathrm{kg} \mathrm{DM})$ on the corresponding diet was therefore studied.

Three rapeseed diets were supplemented with iodine and ferrous sulphate at levels of 280 and $560 \mathrm{mg} \mathrm{Fe}{ }^{++} / \mathrm{kg}$ DM. Two diets were fed as powder and the third as mash. In addition, two groups of 5 rats received, for 10 days, the control diet alone or supplemented with $\mathrm{Fe} \mathrm{SO}_{4}\left(560 \mathrm{mg} \mathrm{Fe} \mathrm{Se}^{++} / \mathrm{kg} \mathrm{DM}\right)$ as mash, to determine the possible effect of $\mathrm{Fe} \mathrm{SO}_{4}$ on diet palatability.

Animals and experimental practices. - One hundred male Sprague Dawley rats weighing a mean of $64 \mathrm{~g}$ were allotted into 10 groups. In addition, ten rats were divided into 2 comparable groups of 5 animals.

The composition and form of presentation of the experimental diets are summarized in table 1 . They were fed ad lib. over a period of 35 days. To facilitate rat

TABLE 1

Main features of the experimental treatments : diet composition, trace element supplementation ( $\mathrm{mg} / \mathrm{kg} \mathrm{DM})$, duration (days) of the distribution period as powder or mash.

\begin{tabular}{rcccccccc}
\hline & Diet & \multicolumn{3}{c}{ Supplementation } & \multicolumn{3}{c}{ Distribution as } \\
\hline $\mathrm{Nr}$ & Protein & $\mathrm{I}^{-}$ & $\mathrm{Cu}^{++}$ & Methion. & $\mathrm{Fe}^{++}$ & Powder & Mash \\
\hline 1 & Fish meal & - & - & - & - & $16 \mathrm{~d}$ & $19 \mathrm{~d}$ \\
2 & Rapeseed & - & - & - & - & $35 \mathrm{~d}$ & - \\
3 & Rapeseed & - & - & - & - & - & $35 \mathrm{~d}$ \\
4 & Rapeseed & 1 & - & - & - & $16 \mathrm{~d}$ & $19 \mathrm{~d}$ \\
5 & Rapeseed & 1 & 315 & - & - & $16 \mathrm{~d}$ & $19 \mathrm{~d}$ \\
6 & Rapeseed & 1 & 630 & - & - & $16 \mathrm{~d}$ & $19 \mathrm{~d}$ \\
7 & Rapeseed & 1 & 630 & 1500 & - & $16 \mathrm{~d}$ & $19 \mathrm{~d}$ \\
8 & Rapeseed & 1 & - & - & 280 & $35 \mathrm{~d}$ & - \\
9 & Rapeseed & 1 & - & - & 560 & $35 \mathrm{~d}$ & - \\
10 & Rapeseed & 1 & - & - & 560 & - & $10 \mathrm{~d}^{*}$ \\
\hline 11 & Fish meal & - & - & - & - & - & $10 \mathrm{~d}$ \\
12 & Rapeseed & - & - & - & 560 & - & $10 \mathrm{~d}$ \\
\hline
\end{tabular}

* Sacrified because of weight loss. 
adaptation to rapeseed diets, these were fed a first mixed with the control diet, at a level of $50 \%$ for 2 days and $75 \%$ for 3 days. Then they were given pure for 30 days.

The method used to avoid wastage of the powdered feeds was found to be inefficient with the unpalatable rapeseed diets. After 16 days, all the diets were supplied as mash except for diets 2,8 and 9 (table 1 ).

Measurements. - The quantities of dry feed supplied, refused and consumed were determined each day. The rats were weighed at 8 a.m. twice a week. At the end of the trial, the rats were anaesthetized with ether. Samples of portal and peripheral blood and the liver, kidneys and thyroid gland were removed. The gut content was eliminated in order to calculate the empty body weight gain (EBWG). The triiodothyronine (T3) and thyroxine (T4) contents of plasma were determined by radio-immunoassay (T3 RIA KIT and T4 RIA KIT, Amersham).

The statistical significance of the results was tested by analysis of variance and the Student's t-test.

\section{Results.}

During the first period of 16 days, the results were biased by wastage of feed by rats that received powdered rapeseed diets. So, results obtained during the second period of 19 days (days 17-35) will be emphasized when most of the rapeseed diets were moistened each morning and fed as mash to avoid all wastage.

Feed consumption and animal growth rate. - During the ad libitum feeding period, growth rate was regular and high for the control group rats : 7.5 and $7.3 \mathrm{~g}$ /day on average during periods 1 and 2 (table 2). Food intake and the growth rate of rats receiving the unsupplemented, powdered rapeseed diet $\left(n^{\circ} 2\right)$ were also regular but $21 \%$ and $36 \%$ lower than those of the control group. Feeding the rapeseed diet as mash $\left(n^{\circ} 3\right)$ reduced food intake by a further $10 \%$ and growth rate by $11 \%$ during the second period (17th to 35th days).

Supplementation of the rapeseed diet with iodine alone $\left(n^{\circ} 4\right)$ had no significant effect on food intake or growth rate during the experimental period. In contrast, supplementation with both iodine and copper at the rate of $315 \mathrm{mg} / \mathrm{kg}$ DM $\left(n^{\circ} 5\right)$ considerably improved rat performance, with mean food intakes and growth rates equal to those of the control group and even slightly higher at the end of the experiment. However, the higher rate of copper supplementation $(630 \mathrm{mg} / \mathrm{kg} \mathrm{DM})\left(\mathrm{n}^{\circ} 6\right)$ caused a significant reduction in food intake $(-6 \%)$ and in growth rate $(-12 \%)$ during all the experimental period, compared with the control group and group $n^{\circ} 5$. Finally, adding methionine $\left(n^{\circ} 7\right)$ to the diet supplemented with the higher level of copper had no beneficial effect on food intake or growth rate. 


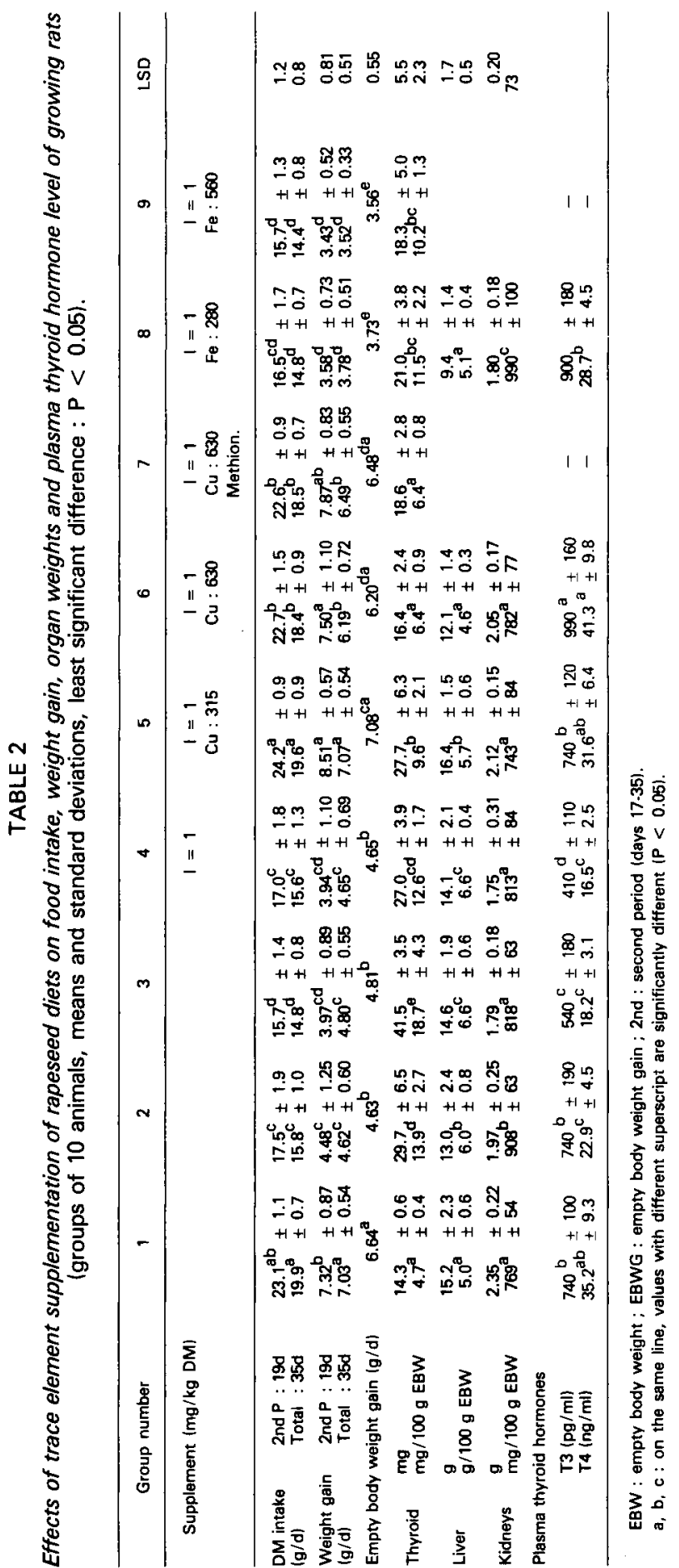

Reproduction, Nutrition, Développernent $n^{\circ} 4$, vol. 27 (1987). - 3 
The rats fed the rapeseed diets supplemented with both iodine and iron (at rates of 280 and $560 \mathrm{mg} / \mathrm{kg} \mathrm{DM}$ ) in the form of powder (nos 8 and 9) had, thoughout the experimental period, intakes of dry feed 28 to $30 \%$ lower than those of the control group and even $8 \%$ less than the group receiving unsupplemented rapeseed $\left(n^{\circ} 2\right)(P<0.05)$. Their growth rates were reduced on an average by 46 and $50 \%$ compared with the control group growth rate and by 18 and $24 \%$, respectively, compared with the group receiving diet $n^{\circ} 2$.

In addition, the rats receiving the rapeseed diet supplemented with iodine and iron and distributed as mash $\left(n^{\circ} 10\right)$ constantly lost weight over 10 days and had to be sacrificed. This would not be due to the ferrous sulphate itself since the 5 rats receiving the control diet supplemented with $\mathrm{Fe} \mathrm{SO}_{4}(560 \mathrm{mg} \mathrm{Fe} / \mathrm{kg} \mathrm{DM})$ in the form of mash ( $\left.n^{\circ} 12\right)$ showed food intakes and growth rates equivalent to those of the corresponding control group $\left(n^{\circ} 11\right)$.

Empty body weight gain (table 2). - The results agree with those obtained for growth rate, with, nevertheless, an advantage for group $n^{\circ} 5$ (rapeseed supplemented in iodine and copper : $315 \mathrm{mg} / \mathrm{kg} \mathrm{DM}$ ) compared with the control group for the same feed intake.

Organ weights (table 2). - To take into account the different rat weights at the end of the experiment, organ weights were expressed per $100 \mathrm{~g}$ of empty body weight (EBW).

The kidney weight of rats receiving the non-supplemented rapeseed diets was increased by $18 \%(P<0.01)$ when feed was in the powdered form and by $6 \%$ (NS) in the case of mash. Supplementation of the rapeseed diet with iodine and ferrous sulphate had no beneficial effect on kidney weight. On the contrary, it further increased kidney weight by $9 \%(P<0.05)$, making a total difference of $29 \%$ compared with the control group. In contrast, supplementation with iodine and copper reduced the relative weight of the kidneys of rats fed the rapeseed diet, such that it was not significantly different from that of the control animals.

The weight of the liver in rats receiving the rapeseed diet as powder or as mash significantly increased by 20 to $33 \%$ compared with the control group. Supplementation of the rapeseed diet with iodine did not reduce liver weight ; the difference remained $33 \%$ with the control group. Supplementation with iodine and copper did have a beneficial effect on liver weight, which was reduced by $14 \%$ with $315 \mathrm{mg} \mathrm{Cu} / \mathrm{kg} \mathrm{DM}$. Liver hypertrophy disappeared completely with $630 \mathrm{mg} \mathrm{Cu} / \mathrm{kg} \mathrm{DM}$. Finally, supplementation of the rapeseed diet with iodine and iron $(280 \mathrm{mg} / \mathrm{kg} \mathrm{DM})$ also appeared to prevent liver hypertrophy. Macroscopic examination did not show any liver anomaly in any group. The colour differences observed seem to be related to the fattening state of the animals.

The weight of the thyroid $(\mathrm{mg} / 100 \mathrm{~g} \mathrm{EBW})$ of rats receiving the rapeseed diets as powder $\left(n^{\circ} 2\right)$ or as mash $\left(n^{\circ} 3\right)$ was three or four times greater than that of control animals. Individual variability was very large and the thyroids were very fragile in group $n^{\circ} 3$. Supplementation of the rapeseed diet with iodine alone 
$\left(n^{\circ} 4\right)$, given first as powder and then as mash for 19 days, reduced thyroid weight by $35 \%$ and led to a similar value to that of the unsupplemented rapeseed diet when feed was given as powder. Thyroid weight remained 2.7 times higher than that of the control group.

Supplementing the rapeseed diet with iodine and copper $(315 \mathrm{mg} \mathrm{Cu} / \mathrm{kg}$ $D M$; group $n^{\circ}$ 5) further reduced thyroid weight, but this remained double that of the control group. However, the thyroid gland appeared in better state than with groups 2, 3 and 4 . With the higher level of copper supplementation $(630 \mathrm{mg}$ $\mathrm{Cu} / \mathrm{kg} \mathrm{DM}$, groups 6 and 7), the goitrogenic effect of rapeseed meal was considerably reduced and thyroid weight was only $37 \%$ greater than that of the control group. However, the thyroids and rat muscles were very pale pink in colour. Supplementation with iodine and iron (groups 8 and 9) only slightly reduced the weight of thyroid gland of rats fed on rapeseed meal. Expressed per $100 \mathrm{~g} \mathrm{EBW}$, thyroid weight remained 2.5 or 2.2 times higher than that of control animals.

Plasma thyroid hormone content (table 2). - Feeding rapeseed meal as powder did not modify the plasma T3 content but reduced by $35 \%$ that of T4 $(P<0.01)$. Feeding the diet as mash accentuated this drop and reduced the plasma T3 content by $27 \%(P<0.01)$. This may be related to the considerable increase in thyroid weight. Supplementation of the rapeseed diet with iodine alone did not improve plasma thyroid hormone contents. Supplementation with both iron and iodine increased T4, and even more, T3 contents, which returned to values similar to those of the control animals. Supplementation with copper and iodine, especially at the highest rate, eliminated the depressive effects of rapeseed meal on the secretion of thyroid hormones.

\section{Discussion.}

The effects of feeding rapeseed meal on feed intake and growth rate of rats were comparable with those observed earlier for glucosinolate contents of $15 \mathrm{mM} / \mathrm{kg} \mathrm{DM}$ (Vermorel, Davicco and Evrard, 1987). These effects were more marked when the diet was fed in the form of mash than when it was powdered, perhaps because of the previous hydrolysis of glucosinolates and thus increased formation of toxic compounds. Although myrosinase activity was suppressed by heating over $70^{\circ} \mathrm{C}$ (Lafrouji, 1986), non-enzymatic hydrolysis of glucosinolates may produce I.T.C. (Ribaillier, 1985).

Contrary to the results of Anke et al. (1980) and Ludke, Schöne and Hennig (1985) on growing pigs, supplementation of the rapeseed diet with iodine alone, at the same level of $1 \mathrm{mg} / \mathrm{kg} \mathrm{DM}$, had no beneficial effect on food intake, rat growth rate and plasma thyroid hormone contents, but slightly reduced thyroid weight. The VTO contents of the diets were similar (1.06 and $1.17 \mathrm{~g} / \mathrm{kg} \mathrm{DM})$, but 
the ITC content of the present rapeseed diet was 3 times higher than that of the diet used by Ludke, Schöne and Hennig (1985) : 0.60 compared with $0.20 \mathrm{~g} / \mathrm{kg}$ DM ; competition with iodine for thyroidal transport may have been greater in this case. Further, it appears that even the control diets fed to pigs by these authors may have been deficient in iodine (Schöne et al., 1986a, b), which could explain the spectacular effect of iodine supplementation.

The considerable increase in rapeseed meal intake and in growth rate resulting from supplementation with both iodine and copper at a level of $315 \mathrm{mg} / \mathrm{kg}$ DM, agrees with the results of Ludke, Schöne and Hennig (1985) and of Rowan and Lawrence (1986) on pigs. In these two species, this supplementation thus gave a performance level similar to that obtained with control diets. In rats, liver and thyroid hypertrophy was largely reduced and that of the kidneys disappeared. At a rate of $630 \mathrm{mg} \mathrm{Cu} / \mathrm{kg} \mathrm{DM}$ the liver was not enlarged and the thyroid weight increased by only $36 \%$. The plasma thyroid hormone contents were, in addition, comparable with those of the control group.

However, this large supplementation with copper $1630 \mathrm{mg} / \mathrm{kg}$ DM compared with the maximal allowance of $250 \mathrm{mg}$ for pigs) caused anaemia, which could be the result of poor iron absorption and explain the reduced animal performance. Finally, and contrary to the hypotheses of Robbins and Baker (1980), supplementation in methionine of the copper-rich diet did not give any significant improvement in the performance of growing rats.

The favorable effects of copper may result from modifications or suppression of the gut microflora (Braude, 1965) - consequently, the production of toxic compounds from glucosinolates could be reduced (Rowan and Lawrence, 1986) - or from the formation of stable complexes with progoitrin, limiting the formation of goitrin (Cansfield and Campbell, 1980) which would explain its antigoitrogenic effects. In addition, Ludke, Schöne and Hennig (1985) showed in vitro that the addition of copper sulphate solutions to rapeseed meal reduced ITC and VTO formation, perhaps as a result of stable linkages with glucosinolates.

The depressive effects of ferrous sulphate added to rapeseed diet on rat growth have not been found in poultry (Menzel, 1983) or in pigs (Bourdon et al., 1984). They cannot be due to unpalatability, since no effects have been noted with the control diet. They probably result from an interaction of the supplement with glucosinolates. In vitro iron salts would favour the formation of thioamides and nitriles from glucosinolates, in place of isothiocyanates and goitrin (Van Etten et al., 1966 ; Austin, Gent and Wolff, 1968 ; Tookey and Wolff, 1970 ; Searle, Chamberlain and Butcher, 1984). This could explain the reduction in liver and thyroid weight and the increased plasma thyroid hormone contents of rats fed the rapeseed diet and the further increase in kidney weight due to the high toxicity of cyanide, the oxidation products of nutriles (Gould et al., 1985). Nitriles are very toxic compounds which reduce growth rate much more than the VTO (Josefsson, 1975 ; Gould, Gumbmann and Daxenbichler, 1980). The considerable toxicity of the diet distributed as mash could result from the formation by autolysis of very large amounts of nitriles, which would reduce the palatability of these diets (Joseffson, 1975). 


\section{Conclusion.}

Supplementation of rapeseed diets containing high concentrations of glucosinolates with copper and iodine gave a $50 \%$ increase in rat growth rate, in comparison with the unsupplemented rapeseed diets and intakes and weight gains identical to those of control animals. In addition, it most considerably reduced liver and kidney hypertrophy and by half thyroid enlargement and reestablished normal plasma thyroid hormone contents. However, at a rate of $315 \mathrm{mg} \mathrm{Cu} / \mathrm{kg}$ DM the thyroid weight was still twice that of control animals. Greater supplementation with copper, which eliminated the effects of glucosinolates on the liver and thyroid, caused a reduction in animal performance, perhaps due to anaemia. Further work will be necessary to determine the optimal rate of copper supplementation according to the glucosinolate content of the diet and to define the optimal composition of a mixture of trace elements based on iodine, copper, zinc and iron to avoid deficiencies due to excess copper.

It would also be useful to study the roles of copper and iron on glucosinolates in vivo, measuring their degradation products in the small intestine and portal blood, but such a study requires reliable and accurate methods for analyzing glucosinolate metabolites in biological fluids.

Recu en septembre 1986. Accepté en mars 1987.

Acknowledgements. - This study was carried out as part of the CETIOM/INRA project "Recherches sur les Oléagineux, $n^{\circ}$ 9058A " with the financial aid of the CETIOM. The authors would like to thank Mme M. J. Davicco for her advice on the analysis of thyroid hormones.

Résumé. Valorisation du tourteau de colza. 4. Influences de la supplémentation en iode, en cuivre et en fer chez le rat en croissance.

Dix groupes de 10 rats mâles en croissance $(65 \mathrm{~g}$ au départ) ont reçu ad libitum pendant 35 jours soit un régime témoin, soit 9 régimes à base de tourteau de colza contenant $15 \mathrm{mM}$ de glucosinolates par $\mathrm{kg}$ de matière sèche et supplémentés ou non en iode seule $\left(1^{-}\right)$en iode et en cuivre $\left(\mathrm{Cu}^{++}\right)(2$ doses), en iode, cuivre et méthionine, ou en iode et fer $\left(\mathrm{Fe}^{++}\right)(2$ doses) (tabl. 1).

Les régimes " colza » non supplémentés et distribués en poudre ou en pâtée ont provoqué des réductions de 24 et $32 \%$ des quantités d'aliment ingéré et de 36 et $46 \%$ du gain de poids vif, des augmentations de 20 et $33 \%$ du poids du foie et ont réduit de 35 et $50 \%$ respectivement la terieur en thyroxine du plasma (tabl. 2 ).

La supplémentation en $\mathrm{I}^{-}$seul n'a pas réduit les effets néfastes du colza. La supplémentation en $\mathrm{I}^{-}$et $\mathrm{Fe}^{++}$a eu une influence défavorable sur l'appétit, le gain de poids et le poids des reins des rats mais des effets bénéfiques sur les poids du foie et de la thyroïde et sur les teneurs en hormones thyroïdiennes du plasma.

La supplémentation en $\mathrm{I}^{-}$et $\mathrm{Cu}^{++}$à la faible dose a supprimé les effets dépressifs du colza sur les performances des rats et réduit ses effets défavorables sur les reins, le foie et la thyroïde ; avec la forte dose de $\mathrm{Cu}^{++}$, ces effets ont été supprimés. Les résultats sont discutés à la lumière des actions connues des cations bivalents sur les glucosinolates. 


\section{References}

ANKE M., SCHWARZ S., HENNIG A., GROPPEL B., GRUN M., ZENKER G., GLOS S., 1980 . Der Einfluss zusächtlicher Zink- und Jodgaben auf rapsextraktionsschrotbedingte Schäden beim Schwein. Monatsh. Veterinärmed., 35 (3), 90-94.

AUSTIN F. L., GENT C. A., WOLFF I. A., 1968. Degradation of natural thioglucosides with ferrous salts. J. agric. Food Chem., 16, 752-755.

BELL J. M., 1984. Nutrients and toxicants in rapeseed meal : a review. J. anim. Sci., 58, 996-1010. BERGNER H., SCHMIDT W., 1972. Untersuchugen zur wirkung von Rapsextraktionsschrot auf das Kükenwachstum. Arch. Tierernähr., 22, 41-47.

BOURDON D., QUERE P., BAUDET J. J., 1982. Valeur énergétique et azotée chez le Porc, d'un tourteau de colza français à faible teneur en glucosinolates et dépelliculé ; comparaison avec un tourteau normal. Journées Recher. Porcine en France, 14, 297-306.

BOURDON D., PEREZ J. M., BAUDET J. J., 1984. Nutritive value and utilization by the growingfinishing pigs of new types of rapeseed oil meals with low-glucosinolate content. In H. Sorensen, Advances in the production and utilization of cruciferous crops (A Seminar in the CEC programme of research on plant protein improvement, Copenhagen, Denmark, Sept. 1984). World crops : production, utilization, description. Vol. 11, 177-198. Martinus Nijhoff, Dr W. Junk Publ., Dordrecht, The Netherlands.

BOURDON D., 1984. Communication personnelle.

CANSFIELD P. E., CAMPBELL L. D., 1980. Spectrophotometry and thin layer chromatography as tools for investigating complex formation between cations and glucosinolate derived products. Analytical chemistry of rapeseed and its products : a symposium, Winnipeg, Manitoba, 5/6 Mai 1980. Canola Council of Canada.

FENWICK G. R., HEANEY R. K., 1983. Glucosinolates and their breakdown products in cruciferous crops, foods and feedingstuffs. Food Chem., 11, 249-271.

GOULD D. H., GUMBMANN M. R., DAXENBICHLER M. E., 1980. Pathological changes in rats fed the crambe meal-glucosinolate hydrolic products, 2S-1-cyano-2-hydroxy-3,4-epithiobutanes (erythro 0 and threo) for 90 days. Food Cosmet. Toxicol., 18, 619-625.

GOULD D. H., FETTMAN M. J., DAXENBICHLER M. E., BARTUSKA B. M., 1985. Functional and structural alterations of the rat kidney induced by the naturally occuring organonitrile $2 \mathrm{~S}$ 1-cyano-2 hydroxy-3,4-epithiobutane. Toxicol. appl. Pharmacol., 78, 190-201.

BRAUDE R., 1965. Copper as a growth stimulant in pigs, 55-66. In Cuprium provita. Symp. Trans., Copper Dev. Ass., London.

JOSEFSSON E., 1975. Influence of glucosinolates and high molecular factors on the nutritional value of low-glucosinolate rapeseed meal. J. Sci. Food Agric., 26, 1299-1310.

JUST A., HANSEN V., JENSEN A., 1982. Quoted by RUNDGREN, 1983.

KRACHT W., MATZKE W., OHLE H. O., 1983. Die Auswirkung von Jod- und Zinksupplementen auf den depressiven Effect von Rapsextraktionsschrot in Schweinefutter. Tierernähr. Fütterung, 13, 126-134.

LAFROUJI A., 1986. Etude de l'activité de la myrosinage. Rapport de fin d'études. Univ. d'Orléans. Faculté des Sciences Fondamentales et Appliquées, pp. 58.

LUDKE H., SCHONE F., HENNIG A., 1985. Der Einfluss von Jodkupfer- und Zink- Zulagen zu Rationen mit hohem Rapsextraktionsschrotanteil auf Wachstum und Schildrüssenfunktion des Mastschweines. 1. Einfluss auf die Mastleistung. Arch. Tierernähr., Berlin, 35, 835-845.

MENZEL E., 1983. Untersuchungen über die Schildrüssenvergrössernde (strumigene) Wirkung Rapshaltiger Rationen in Abhängigkeit von Der Rapssorte, dem Glucosinolatsgehalt und Fütterungszusätzen. Inaug. Diss zur Erlangung des Doktorgrades der Agrarwissenschafttichen Fakultät der Christian-Albrechts Universität Kiel.

MORICE J., 1983. Un nouveau colza : le double-zéro. C.R. Acad. Agric. France, 17, 7-16.

RIBAILLIER D., 1985. Mise au point du dosage des ITC libres dans les tourteaux de colza. Rapport d'activité du CETIOM, pp. 50.

ROBBINS K. R., BAKER D. H., 1980. Effect of dietary sulfur amino-acid level on cupper induced growth depression in rats. Can. J. anim. Sci., 60, 201-202. 
ROWAN T. G., LAWRENCE T. L. J., 1986. Growth, tissue deposition and metabolism studies in growing pigs given low glucosinolate rapeseed meal diets containing different amounts of copper and polyethylene glycol. J. agric. Sci., Camb., 107, 505-513.

RUNDGREN M., 1983. Low-glucosinolate rapeseed products for pigs. A review. Anim. Feed. Sci Technol., 9, 239-262.

SEARLE L. M., CHAMBERLAIN K., BUTCHER D. N., 1984. Preliminary studies on the effects of copper, iron and maganese ions on the degradation of 3-indolylmethylglucosinolate (a constituent of Brassica spp.) by myrosinase. J. Sci. Food Agric., 35, 745-748.

SCHÖNE F., LÜDKE H., GRUHN K., HENNIG A., 1986a. Der Einfluß von Jod-, Kupfer- und Zinkzulagen zu Rationen mit hohem Rapsextraktionsschrotanteil auf Wachstum und Schilddrüsenfunktion des Mastschweines. 2. Mitteilung: Der Einfluß der Jodzulage auf die Nährstoffverdaulichkeit sowie den Protein- und Energieansatz. Arch. Tierernähr., 36, 361-369.

SCHONE F., LÜDKE H., JAHREIS G., SEFFNER W., HENNIG A., 1986b. Der Einfluß von Jod-, Kupfer- und Zinkzulagen zu Rationen mit hohem Rapsextraktionsschrotanteil auf Wachstum und Schilddrüsenfunktion des Mastschweines. 3. Mitteilung : Der Einfluß auf Masse und histomorphometrischen Befund der Schilddrüse sowie die T3- und T4-Konzentration des Serums. Arch. Tierernähr., 36, 371-380.

THOMKE S., ELWINGER K., RUNDGREN M., AHLSTROM B., 1983. Rapeseed meal of Swedish low-glucosinolate type fed to broiler chickens, laying hens and growing-finishing pigs. Acta agric. scand., 33, 75-95.

TOOKEY H. L., WOLFF I. A., 1970. Effect of organic reducing agents and ferrous ion on thioglucosidase activity of Crambe abyssinica seed. Can. J. Biochem., 48, 1024-1028.

VAN ETTEN C. H., DAXENBICHLER M. E., PETERS J. E., TOOKEY H. L., 1966. Variations in enzymatic degradation of Brassica napus seed meals. J. Agric. Food Chem., 14, 426-430.

VERMOREL M., DAVICCO M. J., EVRARD J., 1987. Valorization of rapeseed meal. 3. Effects of glucosinolate content on food intake, weight gain, liver weight and plasma thyroid hormone levels in growing rats. Reprod. Nutr. Dévelop., 27, 57-66. 